\title{
Testing the New World: early modern chemistry and mineral prospection at colonial Jamestown, 1607-1610
}

\author{
Umberto Veronesi $^{1}$ (ID $\cdot$ Thilo Rehren $^{1,2} \cdot$ Beverly Straube $^{3} \cdot$ Marcos Martinón-Torres $^{4}$
}

Received: 30 March 2019 / Accepted: 27 September 2019/Published online: 19 November 2019

(C) The Author(s) 2019

\begin{abstract}
The paper presents new research on an assemblage of metallurgical crucibles used in the assay of minerals at colonial Jamestown. The aim of the study is to explore the range of chemical operations carried out at the site of the first permanent British settlement in America, for which little is known in the documents. The results show that the colonists used high-quality Hessian crucibles to perform tests on different types of complex polymetallic sulphides. This was done to (1) prospect for potential silver and copper ores and (2) to find suitable sources of zinc and tin to be alloyed into brass and bronze through cementation with imported copper offcuts. This study makes a relevant contribution to the growing field of the archaeology of early chemistry and mineral prospection as well as the archaeology of early European colonies in the New World. In particular, material culture can shed fresh light on how European settlers reacted to the many challenges of a new and unfamiliar natural environment and how they tried to make sense and exploit it for financial profit.
\end{abstract}

Keywords Archaeometallurgy $\cdot$ Jamestown $\cdot$ Fire assay $\cdot$ Colonial archaeology $\cdot$ Early modern

\section{Introduction}

The 16th and 17th centuries saw exceptional technological and industrial progress in Europe, fuelled by both the increased consumerism of wealthy classes and a growing scholarly interest in the secrets of nature. Natural philosophy was supported by growing curiosity and empiricism. In the laboratories that proliferated across Europe, chemical industries ranging from the analysis of minerals to the distillation of acids and the manufacture of glass and porcelain were established (Smith 1994; Dupré 2014). Their practitioners manipulated natural substances and made artificial products of both intellectual and commercial value. Metallurgical operations such as fire assay and cupellation, with their attention to

Umberto Veronesi

umberto.veronesi.13@ucl.ac.uk

1 Institute of Archaeology, University College London, London, UK

2 The Cyprus Institute, Nicosia, Cyprus

3 Independent Archaeological Curator and Material Culture Specialist, Newport News, Virginia, USA

4 Department of Archaeology, University of Cambridge, Cambridge, UK quantitative measurements, had a major impact on the development of scientific notions and of modern analytical chemistry (Rehren 1996; Newman 2000; Martinón-Torres and Rehren 2005a). But even the pursuit of alchemical quests such as metallic transmutation triggered experimentation that enabled a deeper understanding of the physico-chemical principles regulating matter (Debus 1998; Newman 2006). Archaeological remains of early laboratory equipment have been discovered at several sites both in Europe and the New World (e.g., Moorhouse et al., 1972; von Osten 1998; Thomas 2009; Bayley and White 2013; Mass and Russow 2015; Addyman 2015). The investigation of such materials can provide important insight into the practical dimension of laboratory practice in the early modern world. In particular, the archaeometric analysis of reaction vessels and the residues within them has proved to be a very powerful tool with regard to the reconstruction of chemical processes, the degree of technical knowledge and understanding of the practitioners and the motivations behind their activities. Pioneering research has been conducted in the field of the archaeology of early modern alchemy and chemistry especially focusing on assemblages of laboratory remains linked to metallurgical operations (Rehren 1996; Martinón-Torres and Rehren 2005b, 2007; Martinón-Torres et al. 2008a; Mongiatti et al. 2009a, b; Martinón-Torres 2012). Relatively little work, however, has 
used archaeology to address developments in early modern experimental chemistry in colonial environments. The New World provided a new universe to test old theories and experiment with unknown materials for both scholarly and commercial purposes in ever-changing contexts of international competition and challenging interaction with indigenous cultures and environments. Previous work on metallurgical remains from a range of sites such as La Isabela in the Dominican Republic (Thibodeau et al. 2007), Frobisher Island (Beaudoin and Auger 2004) and Charlesbourg-Royale (Monette 2013) in Canada, Jamestown in Virginia (MartinónTorres and Rehren 2007; Hudgins et al. 2009) or Roanoke in North Carolina (Nöel Hume 1994: 54-96) have provided hints of this world, but much remains to be unveiled.

Within this context, the present paper concentrates on the trials and experimentation in 17 th-century mineral prospection during the early years of colonial Jamestown, Virginia (1607-1610). The driving force behind the foundation of Jamestown in the spring of 1607 had been the expectation of great profit from the natural and mineral resources of Virginia and the chance for Britain to become less dependent upon imports from the continent. The expedition had been funded by the private investors of the newly born Virginia Company, who had obtained a royal charter for the exploitation of the land (Hudgins 2005; Straube 2013). Metallurgical tests started shortly after the arrival in 1607 under Captain John Martin and were expanded the next year when the first supply ships brought refiners and other metallurgical experts. Alongside the prospection for metals and among other activities, we have archaeological and documentary evidence for glassmaking at these early stages, even though the information given is very scarce and revolves around the "tryall of glasse" that was produced within the first two months and immediately sent to London (Smith 1907: 147; Harrington 1972). Despite the initial enthusiasm of the Virginia Company's investors, this first industrial venture at Jamestown soon ended in failure and little was effectively produced in this period. The excavation at the James Fort since 1994 has brought to light scores of crucible sherds with chemical residues in them as well as other chemistry-related objects (Kelso and Straube 2000: 33-76; Owen et al. 2014; Kelso 2017: 143-164). Here, we analyse an assemblage of laboratory equipment which provides information on the activity carried out at the colony in its very early days and sheds new light on the history of early industrial efforts in North America. A small number of crucibles had previously been analysed offering some initial insight into a complex picture of early industrial experiments (Martinón-Torres and Rehren 2007; Owen et al. 2014). The present study will expand on this and further explore mineral prospection practices and metallurgical trials at the colony, focussing on the ability of the settlers to adapt their skills to the challenges of the new environment.

\section{Materials and methods}

Almost 2000 fragments of laboratory equipment were recovered during the excavation at James Fort. Among them are numerous ceramic crucibles which in most cases display signs of use in high-temperature operations. Fragments of 15 crucibles and a few other finds related to early chemical experiments were chosen from the assemblage to undergo microanalysis trying to cover the span of diversity identified during visual inspection. Despite the fragmentary nature of the samples the majority seems to come from relatively small crucibles showing a layer of residue adhering to the inner surface (Fig. 1). The residues vary in thickness and range from glassy, shiny and lustrous to dull and grainy. Aside from the crucibles, the other samples come from a shard of green window glass, a cupel and a slag cake that probably formed inside a crucible.

Cross-sections of the ceramic body and residue layer were cut, mounted in epoxy resin blocks and polished down to $1 \mu \mathrm{m}$ following standard procedures. The blocks were then carbon-coated prior to analysis with scanning electron microscopy (SEM) with energy dispersive spectrometry (EDS) operated under high-vacuum conditions. Analyses were performed in the Wolfson Archaeological Science Laboratories at the UCL Institute of Archaeology using a Hitachi S-3400 with an Oxford Instruments $\mathrm{X}$-sight energy dispersive spectrometer. The instrument was operated at $20 \mathrm{kV}$ and the working distance was kept at a constant $10 \mathrm{~mm}$. Bulk analyses were normally performed at relatively low magnification on areas between 100 and $300 \mu \mathrm{m}$ across and for a period of $100 \mathrm{~s}$. Smaller areas were chosen for the spot analyses of discrete phases, their size varying according to the size of the phases of interest. Images were obtained in backscattered electron (BSE) mode, which allows to detect compositional differences across the samples indicated by different shades of grey. Results were processed using Oxford Instruments INCA software and are presented as wt $\%$ of oxides for ceramic and slag matrices and for mineral phases with the exception of chlorine which is presented as elemental $\mathrm{wt} \%$, as are all metallic phases. Bulk areas with comparable microstructure were analysed three to five times and the average calculated, whereas discrete phases were normally analysed once. In order to account for corrosion, porosity and to facilitate comparability, data is shown normalised to $100 \mathrm{wt} \%$.

\section{Results}

\section{The crucibles}

Of the 15 crucible fragments analysed, 14 show thin, sandrich bodies made of fine-grained clay tempered almost entirely with round quartz grains varying in size from a few tens up to $500 \mu \mathrm{m}$ across (Fig. 2 left) and elongated voids parallel to the 
Fig. 1 Some of the samples analysed. Top: JR 392A (left) and JR 1545 C (right) showing a black glassy residue adhering to the inner surface. Bottom: JR 2361D (right) with green spots corresponding to corroded brass prills and the crucible slag JR 1115B (left) related to bronze metallurgy
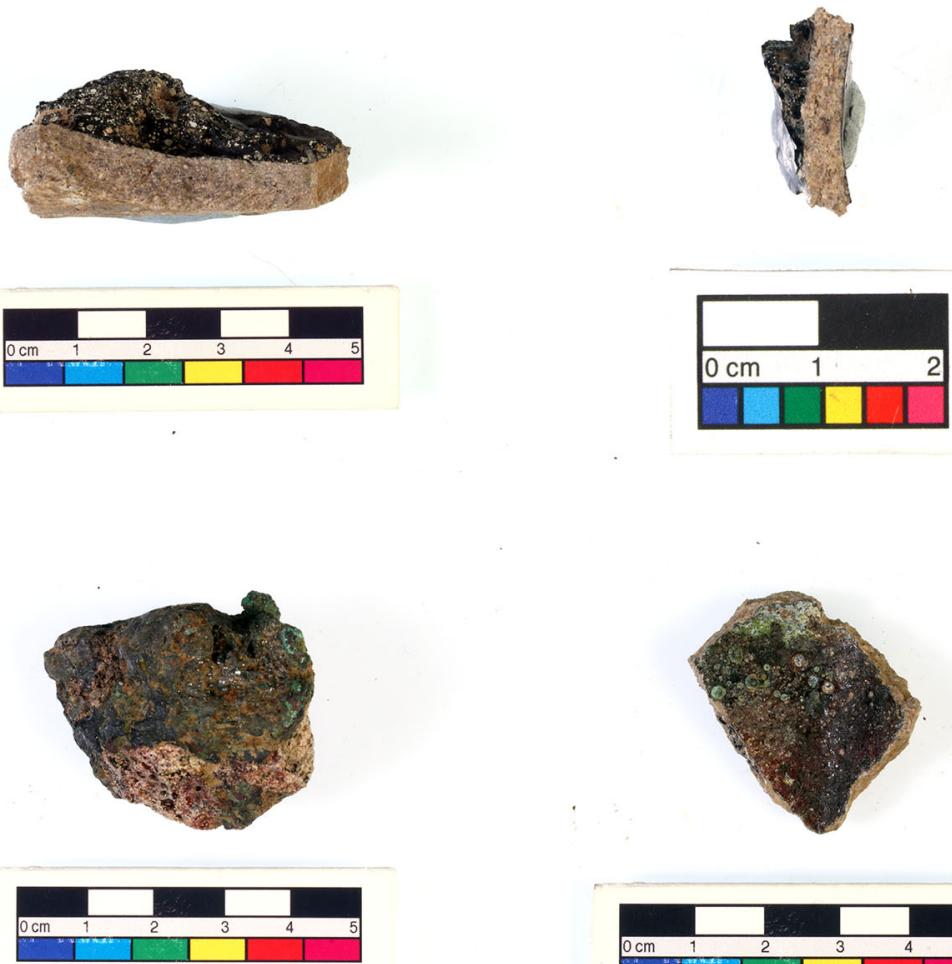
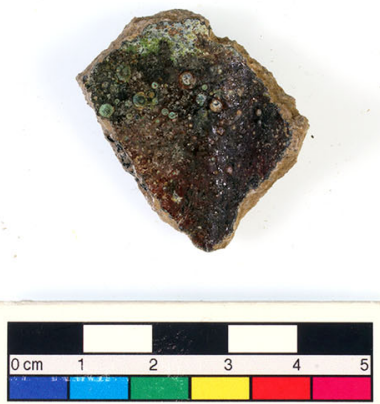

surface. The chemical composition of the ceramic matrices (Table 1) shows levels of alumina in excess of $37 \mathrm{wt} \%$ and low alkalis and iron oxide, much in line with what was observed in the three samples analysed during the preliminary study carried out earlier (Martinón-Torres and Rehren 2007) and with the typical composition of Hessian crucibles (Martinón-Torres and Rehren 2009). These crucibles owed their outstanding thermal refractoriness and resistance to chemical attacks to the special clay they were made with and to the high-temperature pre-firing they underwent (MartinónTorres et al. 2006, 2008b). Only one crucible fragment

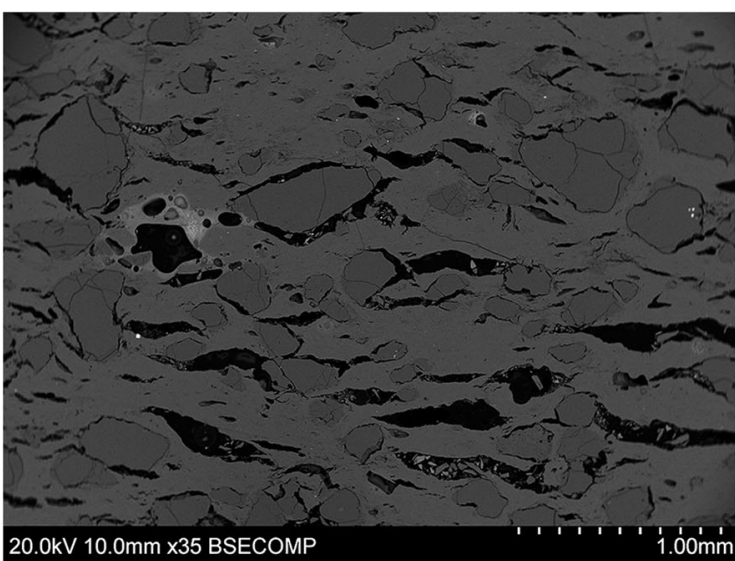

Fig. 2 SEM-BSE micrographs of crucible ceramic fabrics. Left: Hessian crucible JR1957A showing elongated voids and signs of hightemperature firing visible in the cracked quartz grains (magnification $\times$
(A-630) was found to be made of a less refractory type of clay as indicated by the considerably lower levels of alumina and the many small bloating pores in the fabric showing an advanced stage of vitrification of the ceramic body (Fig. 2, right). The composition of the latter is similar to that of one found at the Tower of London Mint (White and Kearns 2010), but a more detailed analysis is needed to confirm this point. The ceramic fabric of all the crucibles displays typical signs of exposure to intense heat and highly reactive chemicals, such as shattered quartz grains and slag penetration through the cracks.

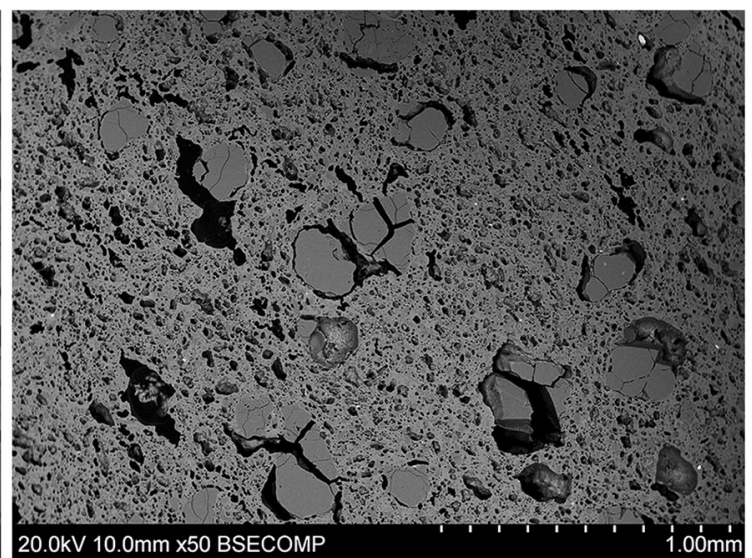

35). Right: non-Hessian crucible A-630 whose matrix shows extensive bloating pores due to lower refractoriness (magnification $\times 50$ ) 
Table 1 Composition of crucible matrices (SEM-EDS analyses, reported in $\mathrm{wt} \%$ )

\begin{tabular}{lllllllll}
\hline Sample & $\mathrm{Na}_{2} \mathrm{O}$ & $\mathrm{MgO}$ & $\mathrm{Al}_{2} \mathrm{O}_{3}$ & $\mathrm{SiO}_{2}$ & $\mathrm{~K}_{2} \mathrm{O}$ & $\mathrm{CaO}$ & $\mathrm{TiO}_{2}$ & $\mathrm{FeO}$ \\
\hline JR1957A & 0.7 & 0.5 & 39.4 & 54.4 & 1.5 & 0.3 & 1.9 & 1.4 \\
JR392A & 0.2 & 0.6 & 39.2 & 54.9 & 1.4 & 0.2 & 1.9 & 1.6 \\
JR1339C & 0.3 & 0.6 & 38.3 & 55.4 & 1.4 & 0.1 & 1.7 & 2.2 \\
JR2436B & 1.2 & 0.4 & 37.9 & 55.4 & 2.1 & 0.2 & 1.7 & 1.1 \\
JR1545C & 0.3 & 0.6 & 37.6 & 56.3 & 1.1 & 0.4 & 1.9 & 1.7 \\
JR1400B I & 0.2 & 0.6 & 39.3 & 55.0 & 1.2 & 0.3 & 1.8 & 1.6 \\
JR1400B II & 0.3 & 0.6 & 38.7 & 55.6 & 1.1 & 0.3 & 1.8 & 1.6 \\
JR1416C & 0.2 & 0.7 & 36.4 & 57.7 & 1.2 & 0.3 & 1.9 & 1.7 \\
JR965B & 0.3 & 0.6 & 36.8 & 57.6 & 1.1 & 0.3 & 1.7 & 1.6 \\
JR2361D & 0.2 & 0.6 & 38.3 & 55.6 & 1.5 & 0.2 & 1.8 & 1.9 \\
JR2718J & 0.2 & 0.6 & 38.9 & 55.1 & 1.4 & 0.3 & 1.8 & 1.8 \\
JR2718M & 0.2 & 0.6 & 38.9 & 55.7 & 1.1 & 0.3 & 1.8 & 1.6 \\
JR2718W & 0.2 & 0.6 & 37.2 & 56.7 & 1.6 & 0.4 & 1.8 & 1.5 \\
A-630 & 0.2 & 0.5 & 23.1 & 70.6 & 1.8 & 0.4 & 1.9 & 1.6 \\
\hline
\end{tabular}

The following sections focus on the metallurgical and chemical residues associated with these crucibles. We present first a succinct description of the analytical results and our initial technical interpretation, before returning to a broader historical contextualisation and discussion.

\section{Silver and gold metallurgy}

Five crucible samples and one cupel fragment can be related to metallurgical operations involving silver. Two of the samples probably represent the base (JR 1400B I) and spout (JR 1400B II) of the same vessel. The residues adhering to the inner and often also to the outer walls of the crucibles vary very much in appearance and range from a welldefined black and glossy layer to simple patches of dark burned areas or orange-reddish spots sometimes showing shiny grains. All of them lack green discolouration often associated with copper corrosion products. There is significant variability in the chemical makeup of the slag layers (Table 2). The glassy background is typically rich in silica (27.6-56.4 wt\% $\mathrm{SiO}_{2}$ ), with variable amounts of oxides of iron (3.5-25 wt \% FeO), aluminium (5.5-15.5 wt\% $\left.\mathrm{Al}_{2} \mathrm{O}_{3}\right)$, calcium (2.7-9.7 wt\% $\mathrm{CaO}$ ) and lead (0.7-11.3 wt\% $\mathrm{PbO})$. Less frequently recurring oxides are those of copper (1$30.4 \mathrm{wt} \% \mathrm{CuO})$, tin $\left(1.6-3.9 \mathrm{wt} \% \mathrm{SnO}_{2}\right)$ and zinc $(1.2-$ $8 \mathrm{wt} \% \mathrm{ZnO})$, detected in JR 1400B I, II and JR 1416C. Finally, the glass phase in samples JR $1339 \mathrm{C}$ and JR $1416 \mathrm{C}$ also contains barium oxide (1.6-33.6 wt\% $\mathrm{BaO}$ ). These variable enrichments are the product of the mineral gangue dissolving in the glass and can change quite dramatically depending on the area analysed. They point to the working of complex minerals whose remnants can sometimes be seen in the slag matrices. An example are the

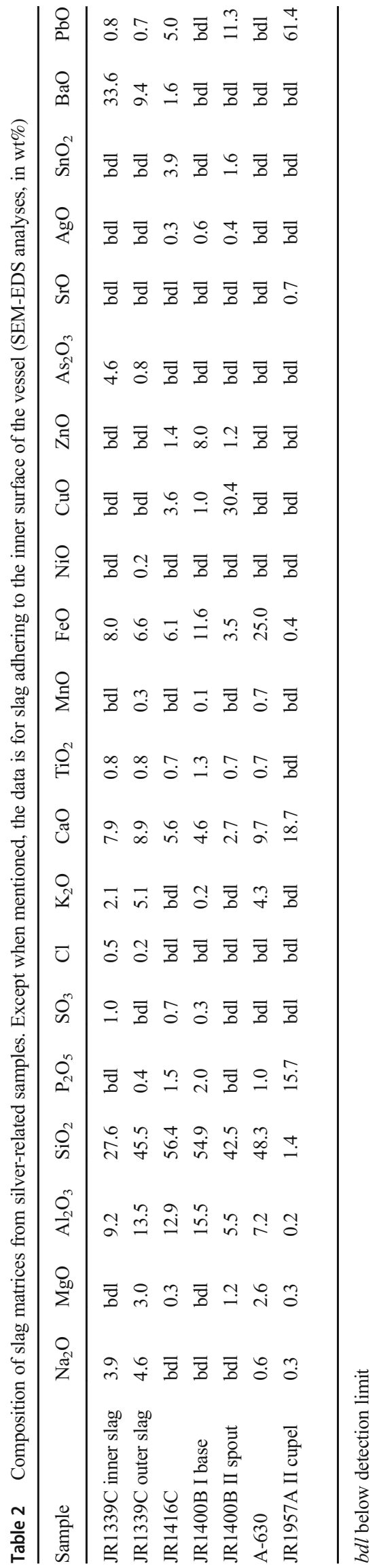


Fig. 3 SEM-BSE micrographs of residues adhering to silver-related crucibles. a JR1400BII (spout of the crucible) showing silver prills surrounded by cuprite areas (magnification $\times 100$ ). b Outer residue of JR1339C with large silver prill (magnification 30x). c Tin-rich mineral relic in JR1416C (magnification $\times 1000)$. d Detail of bone ash grain in cupel JR1957AII (magnification $\times 300$ )
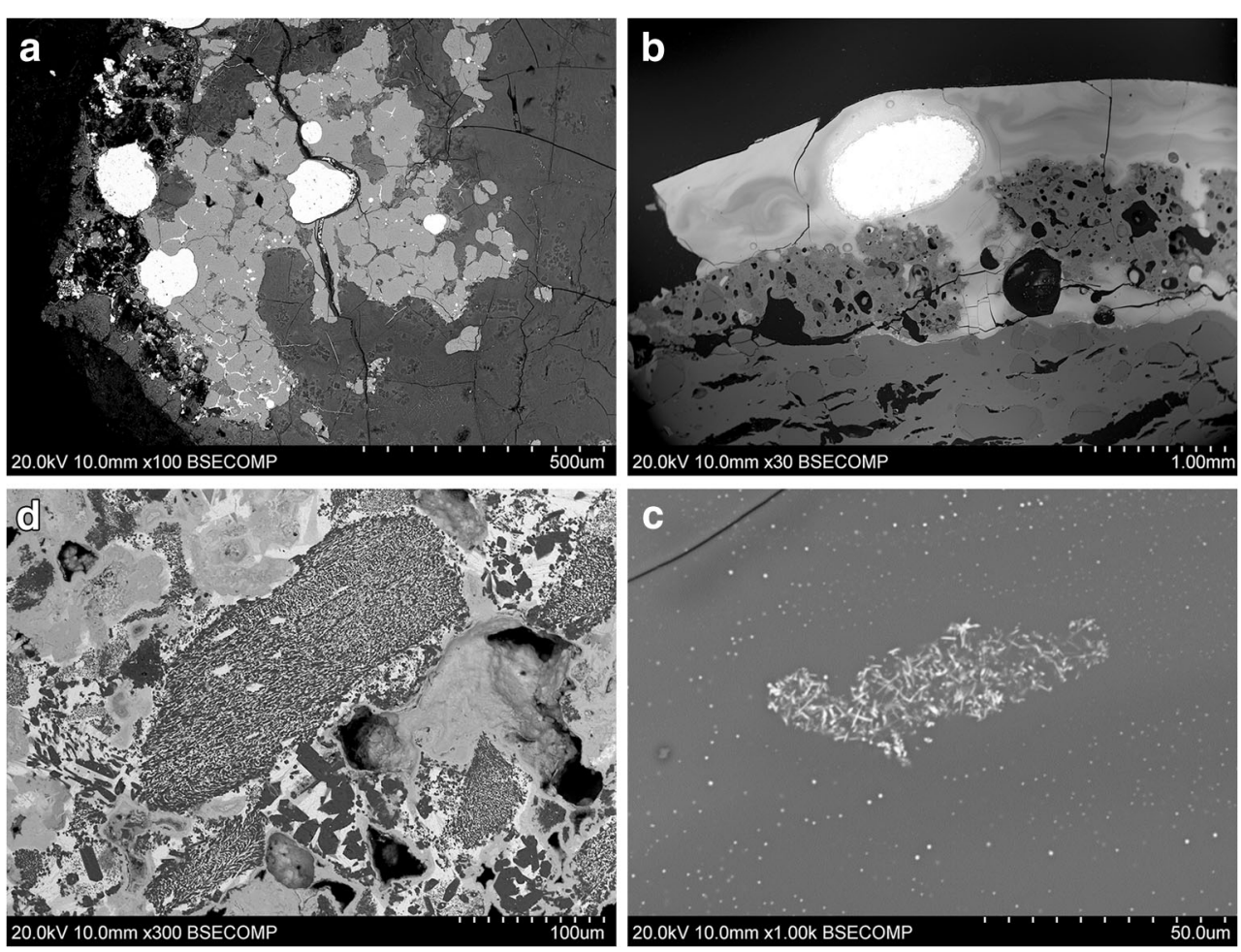

clusters of tin oxide crystals found in sample JR 1416C (Fig. $3 \mathrm{c})$. Other clues as to the type of ores tested come from the analysis of the silver-rich prills scattered throughout the glassy matrices (Fig. 3a, b) (Table 3). Sometimes these have a certain amount of copper with the silver (JR 1416C, JR 1400B I and II), while one prill in JR 1339C shows a remarkable pattern of ore impurities, such as nickel (54.9 wt\% $\mathrm{Ni}$ ), arsenic (31.3 wt $\%$ As) and minor quantities of lead (3.5 wt $\% \mathrm{~Pb})$, cobalt (0.6 wt $\% \mathrm{Co})$, antimony (0.9 wt $\%$ $\mathrm{Sb})$ and sulphur (3.9 wt\% S). Crucible A-630 seems to lack immediate indications of silver metallurgy. Its slag layer is strongly enriched in iron oxide with metallic iron droplets trapped in it, an indication of a pyrite mineral which was probably tested in view of its potential precious metal content. This sample shows similarities with one sample analysed in 2007, which also had been tentatively connected to the interest in gold (Martinón-Torres and Rehren 2007: 94). Lastly, fragment JR 1957A II belongs to a cupel. Cupels were a type of specialised laboratory tool, used in postmedieval times to separate precious metals from the lead bullion into which they had been concentrated during fire assay. Upon heating, the very porous matrix of cupels, usually made with bone ash, absorbed the lead oxide and droplets of gold or silver were left behind (Martinón-Torres et al. 2008a). The bulk composition shows phosphate and lime adding to 34.4 of the total wt $\%$, with the balance being almost entirely the absorbed lead oxide (61.4 wt\% $\mathrm{PbO})$. Small quantities of alumina $\left(0.2 \mathrm{wt} \% \mathrm{Al}_{2} \mathrm{O}_{3}\right)$ magnesia (0.3 wt $\% \mathrm{MgO})$, soda $\left(0.3\right.$ wt $\left.\% \mathrm{Na}_{2} \mathrm{O}\right)$, iron $(0.4 \mathrm{wt} \%$
$\mathrm{FeO})$ and silica $\left(1.4 \mathrm{wt} \% \mathrm{SiO}_{2}\right)$ and around $0.7 \mathrm{wt} \%$ strontium oxide complete the composition of the cupel. Discrete grains with cellular structure like the one in Fig. $3 \mathrm{~d}$ are diagnostic of bone and suggest that the main ingredient of the cupel was bone ash, and this is also supported by the $\mathrm{CaO}: \mathrm{P} 2 \mathrm{O} 5$ ratio around 1.2 , and consistent with this proposition. (cfr Girbal 2011; Ulseth et al. 2015; Hsu and Martinón-Torres 2019). However, the relatively high strontium oxide remains to be explained and may point to an additional ingredient, perhaps shell or pulverised fish bones, (cfr Hoover and Hoover 1950: 229-231; Sisco and Smith 1951: 31; Naga et al. 2014).

In sum, the results outlined point to operations of mineral prospection aimed to concentrate the noble metal in a lead bullion before isolating and quantifying it through cupellation. The minerals tested most likely came from complex bodies of polymetallic sulphides as indicated by the presence of sulphur and the suite of minor components detected in the metallic droplets. An aspect worth noting in all of these slag layers is the relatively low amounts of lead oxide in most samples. Indeed, lead was normally added as a noble metal collector in mineral assays in order to form a regulus at the bottom of the vessel containing the precious metals from the ore tested (Hoover and Hoover 1950: 239; Sisco and Smith 1951: 45-46; Smith and Gnudi 1990: 139). Thus, lead would have been preferentially enriched in this metal phase collecting at the bottom of the crucible, rather than in the oxidised slag layer forming on top (Mongiatti et al. 2009a; Liu et al. 2015). 
Table 3 Composition of metallic prills from silver-related samples (SEM-EDS analyses, in wt\%)

\begin{tabular}{|c|c|c|c|c|c|c|c|c|c|c|c|c|c|c|}
\hline Sample & $\mathrm{O}$ & $\mathrm{P}$ & $\mathrm{S}$ & $\mathrm{Cl}$ & $\mathrm{Fe}$ & Co & $\mathrm{Ni}$ & $\mathrm{Cu}$ & As & $\mathrm{Br}$ & $\mathrm{Ag}$ & $\mathrm{Sn}$ & $\mathrm{Sb}$ & $\mathrm{Pb}$ \\
\hline 1339C inner slag & 14.8 & bdl & 8.2 & 0.2 & bdl & bdl & bdl & bdl & bdl & bdl & 34.6 & bdl & bdl & 42.2 \\
\hline 1339C outer slag & 3.0 & bdl & 3.9 & bdl & bdl & 0.6 & 54.9 & bdl & 31.3 & bdl & 1.9 & bdl & 0.9 & 3.5 \\
\hline $1416 \mathrm{C}$ & 6.5 & bdl & bdl & 3.9 & bdl & bdl & bdl & 2.8 & bdl & 2.2 & 84.6 & bdl & bdl & bdl \\
\hline $1416 \mathrm{C}$ & 8.1 & bdl & 0.1 & 0.3 & bdl & bdl & bdl & 4.9 & bdl & bdl & 86.6 & bdl & bdl & bdl \\
\hline 1400B II spout & 1.9 & bdl & bdl & 0.1 & bdl & bdl & bdl & 6.7 & bdl & bdl & 91.3 & bdl & bdl & bdl \\
\hline 1400B II spout & bdl & bdl & bdl & bdl & bdl & bdl & bdl & 6.1 & bdl & bdl & 93.9 & bdl & bdl & bdl \\
\hline 1400B II spout & 2.5 & bdl & bdl & bdl & bdl & bdl & bdl & 1.7 & bdl & bdl & 95.8 & bdl & bdl & bdl \\
\hline 1400B II spout & 0.3 & bdl & bdl & bdl & bdl & bdl & bdl & 0.6 & bdl & bdl & 99.2 & bdl & bdl & bdl \\
\hline 1400B II spout & 1.9 & bdl & bdl & bdl & bdl & bdl & bdl & 3.3 & bdl & bdl & 94.8 & bdl & bdl & bdl \\
\hline 1400B II spout & bdl & bdl & bdl & bdl & bdl & bdl & bdl & 1.1 & bdl & bdl & 98.9 & bdl & bdl & bdl \\
\hline A-630 & bdl & 0.6 & bdl & bdl & 96.0 & bdl & bdl & 2.9 & bdl & bdl & bdl & 0.5 & bdl & bdl \\
\hline A-630 & bdl & 0.3 & bdl & bdl & 92.5 & bdl & 0.7 & 5.4 & bdl & bdl & bdl & 1.1 & bdl & bdl \\
\hline A-630 & bdl & bdl & bdl & bdl & 97.1 & bdl & bdl & 2.9 & bdl & bdl & bdl & bdl & bdl & bdl \\
\hline A-630 & bdl & 1.7 & bdl & bdl & 97.0 & bdl & bdl & 1.3 & bdl & bdl & bdl & bdl & bdl & bdl \\
\hline A-630 & bdl & 0.7 & bdl & bdl & 98.8 & bdl & bdl & 0.5 & bdl & bdl & bdl & bdl & bdl & bdl \\
\hline A-630 & bdl & 0.4 & bdl & bdl & 99.0 & bdl & bdl & 0.7 & bdl & bdl & bdl & bdl & bdl & bdl \\
\hline
\end{tabular}

\section{Copper metallurgy}

Indications of copper-related metallurgical reactions are found in three crucible fragments and one slag lump (Table 4). Crucible JR 965B has a slag with enrichments in the oxides of iron and copper (averages of $22.5 \mathrm{wt} \% \mathrm{FeO}$ and $6.4 \mathrm{wt} \%$ $\mathrm{CuO})$, and in soda $\left(9 \mathrm{wt} \% \mathrm{Na}_{2} \mathrm{O}\right)$. Angular crystals of newly formed magnetite, as well as rounded clusters of residual magnetite can be seen scattered in the matrix (Fig. 4a) and their analysis shows they contain up to around $4 \mathrm{wt} \% \mathrm{CuO}$, around $1.5 \mathrm{wt} \% \mathrm{NiO}$ and in some cases up to $2.5 \mathrm{wt} \% \mathrm{PbO}$. The metallic droplets in this sample are of almost pure copper and one appears surrounded by a copper sulphide shell (Fig. 4b) (Table 5). In light of these results, we interpret this residue as the by-product of the reducing fusion of an iron-rich sulphide mineral to assess its copper content. The presence of alkali and earth alkali oxides may derive from the addition of charcoal as a reducing agent within the crucible, the use of a flux and/or the presence of feldspars in the gangue. Another sherd, JR 2361D, has green corroded globules visible on its internal surface (Fig. 4c). SEM analysis (Table 5) shows these are brass prills with approximately $11 \mathrm{wt} \%$ zinc and small quantities of nickel, sulphur and arsenic (respectively 0.3$0.4 \mathrm{wt} \% \mathrm{Ni}, 0.5 \mathrm{wt} \% \mathrm{~S}$ and $0.5-1.5 \mathrm{wt} \% \mathrm{As}$ ) and in one case an outer layer of copper sulphide. The potential use of this crucible in brass making seems to be confirmed by the composition of the glassy residue within which the prills are trapped. Besides some $1 \mathrm{wt} \%$ zinc oxide, the levels of lime $(17.9 \mathrm{wt} \% \mathrm{CaO})$ and magnesia $(3.7 \mathrm{wt} \% \mathrm{MgO})$ point to the presence of charcoal in the charge, essential for cementation (Martinón-Torres and Rehren 2002, Martinón-Torres and Rehren 2007, 89), although this enrichment could also derive, at least in part, from zinc ore gangue. The connection of Jamestown to brass making is further discussed in "Zinc and tin testing" section. Sample JR 2718J shows only very faint traces of metallurgical use. The slag layer has a minor enrichment in copper oxide which varies from none to around $0.3 \mathrm{wt} \% \mathrm{CuO}$. The sample has a direct parallel in one sample from the 2007 pilot study, which was interpreted as a casting vessel (Martinón-Torres and Rehren 2007: 86-87). The size

Table 4 Composition of slag matrices adhering to the inner walls of copper-related samples (SEM-EDS analyses, in wt $\%$ )

\begin{tabular}{lllllllllllllllll}
\hline Sample & $\mathrm{Na}_{2} \mathrm{O}$ & $\mathrm{MgO}$ & $\mathrm{Al}_{2} \mathrm{O}_{3}$ & $\mathrm{SiO}_{2}$ & $\mathrm{P}_{2} \mathrm{O}_{5}$ & $\mathrm{SO}_{3}$ & $\mathrm{Cl}$ & $\mathrm{K}_{2} \mathrm{O}$ & $\mathrm{CaO}$ & $\mathrm{TiO}_{2}$ & $\mathrm{MnO}$ & $\mathrm{FeO}$ & $\mathrm{CuO}$ & $\mathrm{SnO}$ & $\mathrm{ZnO}$ & $\mathrm{PbO}$ \\
\hline JR965B & 9.0 & 1.0 & 3.7 & 42.2 & 1.6 & bdl & 0.9 & 6.2 & 4.3 & 0.6 & 0.2 & 22.5 & 6.4 & bdl & bdl & 1.4 \\
JR2718J & 1.7 & 1.3 & 6.6 & 62.0 & 0.2 & bdl & bdl & 17.3 & 7.1 & 1.0 & 0.3 & 2.1 & 0.3 & bdl & bdl & bdl \\
JR2361D & 2.7 & 3.7 & 7.0 & 53.1 & 0.9 & 0.5 & 0.2 & 10.5 & 17.9 & 0.8 & 0.4 & 0.8 & 0.4 & bdl & 1.0 & bdl \\
JR1115B & 0.7 & 0.6 & 15.4 & 59.4 & bdl & bdl & bdl & 2.9 & 0.2 & 1.4 & bdl & 3.1 & 13.5 & 2.0 & bdl & 0.8 \\
\hline
\end{tabular}

$b d l$ below detection limit 
Fig. 4 SEM-BSE micrographs showing the microstructure of copper-related samples. a JR965B with nickeliferous magnetite (mid grey) and metallic copper globules (white). Note the angular crystals indicating that the magnetite was newly formed, as well as rounded clusters of residual magnetite towards the centre of the image (magnification $x$ 500). b Copper prill with $\mathrm{Cu}-\mathrm{S}$ shell (grey) in the same sample (magnification $\times 300$ ). $\mathbf{c}$ Brass prill trapped in the inner residue of sample JR2361D (magnification $\times 30$ ). $\mathbf{d}$ Low-tin bronze area (mid grey) and $\mathrm{SnO}_{2}$ crystals (bright) in JR1115B (magnification $\times 100$ )
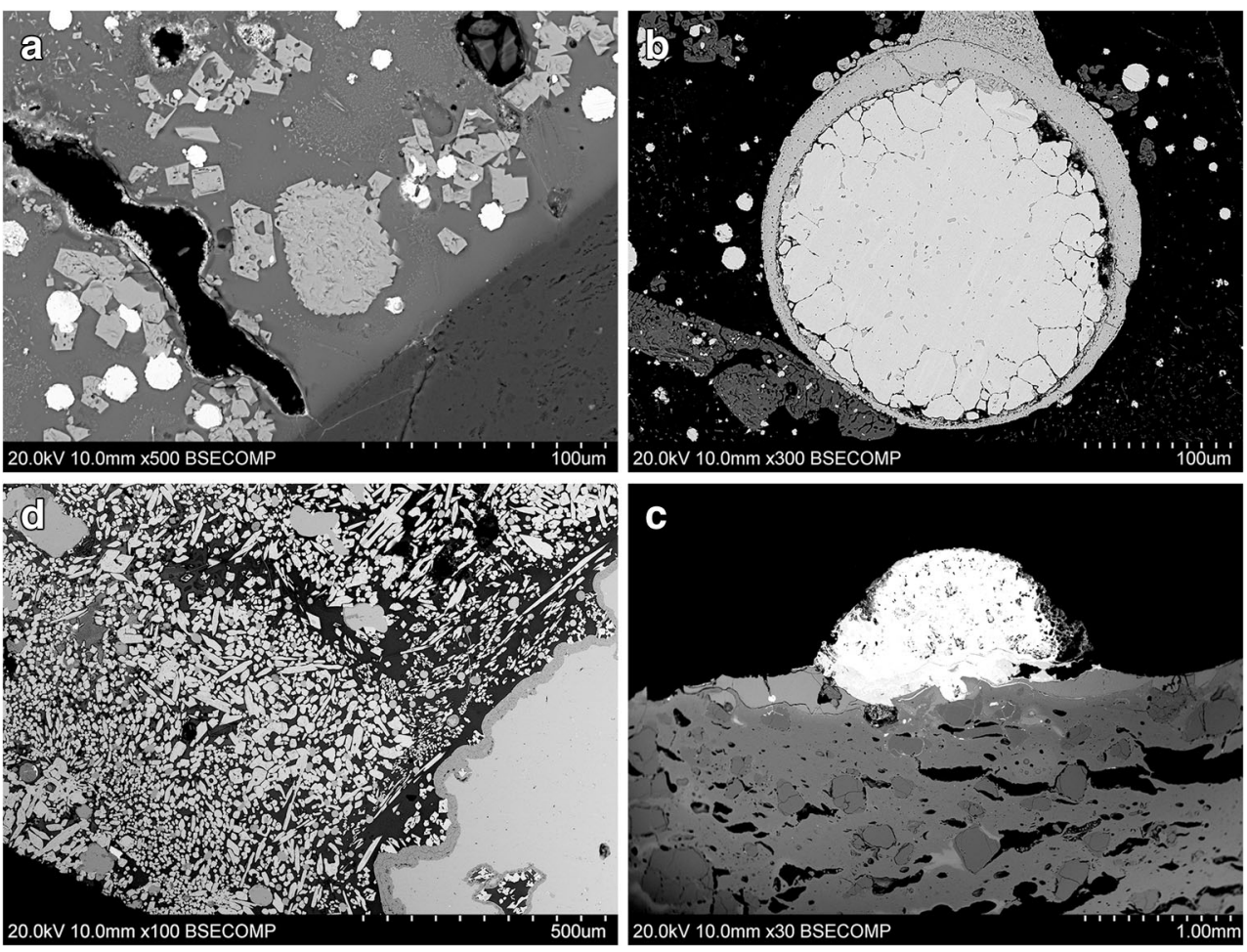

Table 5 Composition of metallic prills from copper-related samples (SEM-EDS analyses, in wt\%)

\begin{tabular}{|c|c|c|c|c|c|c|c|c|c|c|c|c|}
\hline Sample & $\mathrm{O}$ & $\mathrm{P}$ & $\mathrm{S}$ & $\mathrm{Cl}$ & $\mathrm{Fe}$ & $\mathrm{Ni}$ & $\mathrm{Cu}$ & $\mathrm{Zn}$ & As & Sn & $\mathrm{Sb}$ & $\mathrm{Pb}$ \\
\hline 965B & 1.1 & bdl & bdl & bdl & 0.3 & bdl & 98.5 & bdl & bdl & bdl & bdl & bdl \\
\hline $965 \mathrm{~B}$ & 1.0 & bdl & 0.4 & bdl & bdl & bdl & 98.2 & bdl & bdl & bdl & 0.4 & bdl \\
\hline 965B & 0.8 & bdl & bdl & bdl & 1.9 & bdl & 97.2 & bdl & bdl & bdl & bdl & bdl \\
\hline $965 \mathrm{~B}$ & 0.9 & bdl & bdl & bdl & 0.5 & bdl & 98.6 & bdl & bdl & bdl & bdl & bdl \\
\hline $965 \mathrm{~B}$ & 0.9 & bdl & bdl & bdl & 2.3 & bdl & 96.8 & bdl & bdl & bdl & bdl & bdl \\
\hline $965 \mathrm{~B}$ & 1.8 & bdl & bdl & bdl & 3.8 & bdl & 94.4 & bdl & bdl & bdl & bdl & bdl \\
\hline $965 \mathrm{~B}$ & 1.1 & bdl & bdl & bdl & 3.5 & bdl & 95.4 & bdl & bdl & bdl & bdl & bdl \\
\hline $965 \mathrm{~B}$ & 0.8 & bdl & bdl & bdl & 3.6 & bdl & 95.7 & bdl & bdl & bdl & bdl & bdl \\
\hline $965 \mathrm{~B}$ & 1.4 & bdl & bdl & bdl & 4.5 & bdl & 94.1 & bdl & bdl & bdl & bdl & bdl \\
\hline $2718 \mathrm{~J}$ & 9.1 & bdl & bdl & bdl & 0.5 & bdl & 90.4 & bdl & bdl & bdl & bdl & bdl \\
\hline 2361D & 1.3 & bdl & 0.5 & bdl & 8 & 0.4 & 83.6 & 12.3 & bdl & bdl & bdl & 1.2 \\
\hline 2361D & 1.9 & bdl & 0.5 & 0.2 & 4 & 0.4 & 83.4 & 11.9 & bdl & bdl & bdl & 1.3 \\
\hline 2361D & 1.3 & bdl & bdl & bdl & 0.5 & 0.3 & 86.2 & 11.6 & bdl & bdl & bdl & 1 \\
\hline 2361D & 1.2 & bdl & bdl & bdl & 0.2 & 0.3 & 86.8 & 10.9 & 0.5 & bdl & bdl & . \\
\hline 2361D & 1.7 & 1.4 & bdl & bdl & 9.1 & bdl & 73.6 & 10.6 & 1.5 & bdl & 0.8 & 10 \\
\hline $1115 \mathrm{~B}$ & 1.9 & bdl & bdl & bdl & bdl & bdl & 98.1 & bdl & bdl & bdl & bdl & bdl \\
\hline 1115B & 1.3 & bdl & bdl & bdl & bdl & bdl & 85.3 & bdl & bdl & 13.5 & bdl & bdl \\
\hline $1115 \mathrm{~B}$ & bdl & bdl & bdl & bdl & bdl & bdl & 86.4 & bdl & bdl & 13.6 & bdl & bdl \\
\hline $1115 \mathrm{~B}$ & bdl & bdl & bdl & bdl & bdl & bdl & 56.3 & bdl & bdl & 43.7 & bdl & bdl \\
\hline 1115B & 3.9 & bdl & bdl & 0.2 & bdl & bdl & 48.3 & bdl & bdl & 47.6 & bdl & bdl \\
\hline 1115B & 1.0 & bdl & 0.2 & bdl & bdl & bdl & 97.6 & bdl & bdl & 1.2 & bdl & bdl \\
\hline
\end{tabular}

$b d l$ below detection limit and shape of the slag lump JR 1115B fits the round bottom of Hessian crucibles and is therefore indicative of the fact that it formed inside one (Fig. 1, bottom-left). Within the aluminium silicate matrix probably resulting from the vitrification of the crucible fabric the microstructure shows several metallic areas ranging from small rounded prills to large amorphous phases (Fig. 4d). These are bronzes with tin ranging from just a few percent to exceptionally high levels of around $50 \mathrm{wt} \%$ (Table 5). Such remarkable variability is a strong indication that the vessel was used for active alloying of copper with a fresh source of tin, rather than for simple re-melting of bronze (Renzi and Rovira-Llorens, 2016; Rademakers et al. 2018). While it is harder to tell conclusively whether the alloying process made use of tin in metallic or mineral form, the latter option seems more likely as the clusters of tin oxide crystals visible in Fig. 4d might represent pseudomorphs of mineral cassiterite. The presence of around $0.5 \mathrm{wt} \%$ tantalum in many of the cassiterite crystals is further clue to tin entering in mineral form since tantalite, a Ta-rich mineral is often associated with tin deposits (Farci et al. 2017). Around the prills and particularly the large metallic areas are numerous elongated tin oxide crystals caused by the preferential oxidation of tin from the bronze melt (Dungworth 2000; Rademakers and Farci 2018).

Overall, these copper-related samples point to two distinct metallurgical processes; on the one hand, the assay of ironrich sulphide minerals to assess their copper content, and on the other hand, operations of alloying, melting or casting of tin bronzes and brass. 


\section{Other minerals tested}

A third category of remains includes a few fragments of crucible walls with a black, translucent residue on the internal surface (Fig. 1, top-left). Their appearance is not too dissimilar to those of the samples reported previously, but their microstructure and chemical composition set them apart from the rest of the assemblage. Indeed, they bear no detectable trace of either silver or copper and, except for JR 392A, they lack metallic droplets trapped in the glassy residue that would facilitate a more conclusive adscription to metallurgy. Instead, they contain abundant residual minerals that for the most part consist of partially melted feldspar that range from the potassium end of the spectrum to more frequent sodium-potassium ones (Fig. 5a). Their presence is responsible for the strong enrichment of the slag matrices of these samples in both alkalis (5.3-8.9 $\mathrm{wt} \% \mathrm{Na}_{2} \mathrm{O}$ and $13.1-17.9 \mathrm{wt} \% \mathrm{~K}_{2} \mathrm{O}$ ) and alumina (8.7-11.9 wt\% $\mathrm{Al}_{2} \mathrm{O}_{3}$ ), while the iron oxide content (2.5 to $4.5 \mathrm{wt} \% \mathrm{FeO}$ ) points to the presence of pyrite in the original charge. Sample JR 392A represents an exception as its residue contains potassium feldspar crystals with lead prills, and an associated lead oxide enrichment in the glass phase (1.3 wt $\%$ $\mathrm{PbO}$ ) (Table 6) (Fig. 5b-d). The prills can contain impurities of sulphur, nickel, arsenic and antimony (Table 7). Since such large amount of feldspars was not found in the crucible fabrics, their occurrence in the vitrified layer cannot be assumed to derive from molten ceramics but rather they seem to indicate a different type of mineral being processed within these crucibles. One possibility is the processing of galena-rich feldspar, known to occur in certain pegmatites. Our initial thoughts on the technical interpretation of these crucibles are presented in the "Mineral prospection and experiments for the industry" section (cfr Rehren et al. 2019 for further discussion).

\section{Other}

One sample, JR 2G, is a fragment of green window glass with notable enrichments in lime $(22.6 \mathrm{wt} \% \mathrm{CaO})$ and phosphate that indicate the use of plant ashes as ingredients. The low amounts of alkalis $\left(0.8 \mathrm{wt} \% \mathrm{Na}_{2} \mathrm{O}\right.$ and $\left.4.5 \mathrm{wt} \% \mathrm{~K}_{2} \mathrm{O}\right)$ allow to ascribe this fragment to the high lime low alkali glass type, very common in post-medieval Europe (Dungworth 2011, 2012; Dungworth et al. 2013). Many more fragments of the same kind were found at Jamestown, and they probably are to be seen as the fort's reservoir of scrap glass brought from Europe (cf samples analysed by Owen et al. 2014). Besides manufacturing objects useful for everyday life, scrap glass may also have been employed as a flux in assaying operations to promote the formation of slag (Mongiatti et al. 2009a; Rehren and Nixon 2014). The remaining samples JR $2718 \mathrm{~W}, \mathrm{JR} 2718 \mathrm{M}$ and JR 2436B are crucible fragments but cannot be confidently ascribed to any of the operations outlined above. SEM-EDS results for the bulk chemical composition of the residue found adhering to their inner surfaces are shown in Table 8. JR 2718W has a grainy and corrodedlooking residue (Fig. 6a) whose bulk composition is made of lead chloride (ca. $73 \mathrm{wt} \% \mathrm{~Pb}$ and $16 \mathrm{wt} \% \mathrm{Cl}$ ) with around $11 \mathrm{wt} \%$ oxygen. Within this background are frequent lead
Fig. 5 SEM-BSE micrographs showing the feldspar-rich residue adhering to some crucibles. a JR 1957A with feldspar inclusions (magnification $\times 30$ ). b Interface between ceramic and residue layer of JR 392A. Note the grey feldspar crystals in the glassy matrix and the large metallic prill that leaked in the crucible fabric (magnification $\times 30$ ).c, $\mathbf{d}$ Details of $\mathrm{Pb}$-feldspar inclusion with $\mathrm{Pb}$ rich prills (magnification $\times 200, \times$ 150)
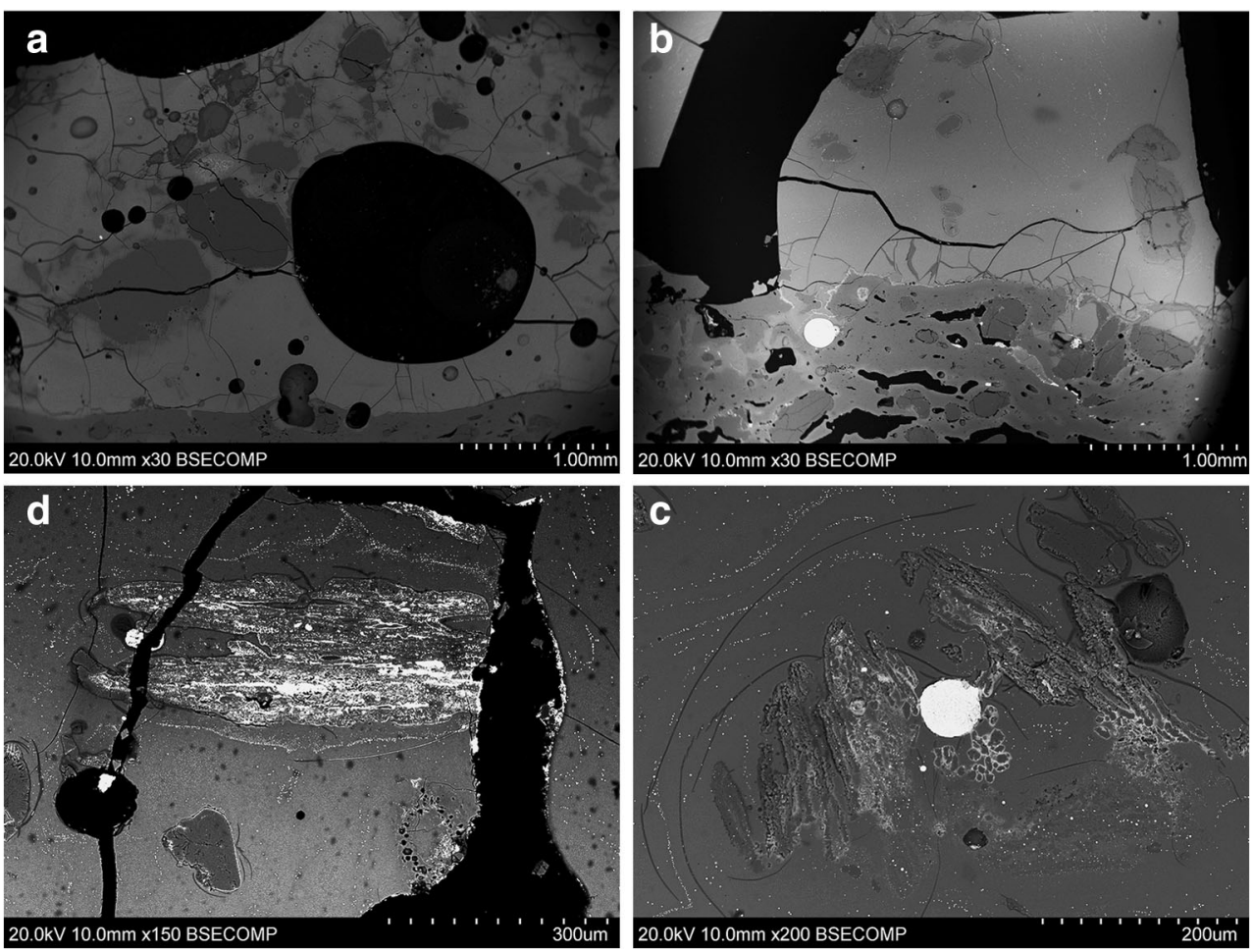
Table 6 Composition of residue matrix on the inner walls of feldspar-rich samples (SEM-EDS analyses, in wt\%)

\begin{tabular}{llllllllllllll}
\hline Sample & $\mathrm{Na}_{2} \mathrm{O}$ & $\mathrm{MgO}$ & $\mathrm{Al}_{2} \mathrm{O}_{3}$ & $\mathrm{SiO}_{2}$ & $\mathrm{P}_{2} \mathrm{O}_{5}$ & $\mathrm{SO}_{3}$ & $\mathrm{Cl}$ & $\mathrm{K}_{2} \mathrm{O}$ & $\mathrm{CaO}$ & $\mathrm{TiO}_{2}$ & $\mathrm{FeO}^{2}$ & $\mathrm{As}_{2} \mathrm{O}_{3}$ & $\mathrm{PbO}$ \\
\hline JR1957A & 8.6 & 1.8 & 8.7 & 57.9 & bdl & bdl & 0.7 & 14.0 & 2.6 & 0.7 & 4.5 & bdl & 0.5 \\
JR1545C & 8.9 & 0.7 & 11.9 & 60.0 & bdl & 0.3 & 0.6 & 13.1 & 1.0 & 0.8 & 2.5 & bdl & bdl \\
JR392A & 5.3 & 2.4 & 11.2 & 52.1 & 0.4 & 0.6 & 0.5 & 17.9 & 4.6 & 0.9 & 2.5 & 0.4 & 1.3 \\
\hline
\end{tabular}

$b d l$ below detection limit

sulphide prills representing galena remnants (ca. $87 \mathrm{wt} \% \mathrm{~Pb}$, $13 \mathrm{wt} \% \mathrm{~S}$ ). JR $2718 \mathrm{M}$ also has a corroded residue, but this one looks glassy rather than grainy (Fig. 6b). The bulk composition is rich in silica and alumina (respectively $66.9 \mathrm{wt} \%$ $\mathrm{SiO}_{2}$ and $14.7 \mathrm{wt} \% \mathrm{Al}_{2} \mathrm{O}_{3}$ ), most likely due to the alkalis having leached away through weathering. The partially melted phases visible in its microstructure are feldspars and might link this crucible to similar operations as the testing of feldspar-rich minerals discussed in the "Other minerals tested" section (cfr Rehren et al. 2019 for further discussion). However, the severe corrosion does not allow a definite interpretation of this sample. Lastly, crucible fragment JR 2436B contains a glassy residue and a high degree of interaction between this and the ceramic body (Fig. 6c). The composition of the glassy layer, very high in lime $(20.1 \mathrm{wt} \% \mathrm{CaO})$, is remarkably similar to the glass window JR 26, but deviates from it in that it also shows high alumina ( $14.9 \mathrm{wt} \% \mathrm{Al}_{2} \mathrm{O}_{3}$ ), most likely the result of contamination from the ceramic. A charcoal impression can be seen in the glassy matrix, its celllike structure surrounded by some tiny metal prills formed around it due to the highly reducing conditions in that area (Fig. 6d). Their composition is mostly iron (ca. $85 \mathrm{wt} \% \mathrm{Fe}$ ) with around $13 \mathrm{wt} \%$ phosphorus and some $0.5 \mathrm{wt} \%$ antimony, plus minor components absorbed from the surrounding melt. This composition is suggestive of the processing of iron minerals under particularly reducing conditions.

\section{Mineral prospection and experiments for the industry}

The analytical results offer important information regarding the various crucible charges and the chemical processes that

Table 7 Composition of the metallic globules found in the residue layer of sample JR392A (SEM-EDS analyses, in wt\%)

\begin{tabular}{lllllll}
\hline Sample & $\mathrm{O}$ & $\mathrm{S}$ & $\mathrm{Fe}$ & $\mathrm{Ni}$ & $\mathrm{Sb}$ & $\mathrm{Pb}$ \\
\hline JR 392A & 8.5 & 3.3 & 0.3 & 5.1 & 0.5 & 82.2 \\
JR 392A & 10.6 & 11.8 & 0.6 & 0.6 & bdl & 76.5 \\
JR 392A & 35.7 & 0.6 & 10.4 & bdl & bdl & 53.3 \\
JR 392A & 8.3 & 12.3 & bdl & bdl & bdl & 79.4 \\
\hline
\end{tabular}

bdl below detection limit these underwent in the furnace, and lay the foundations for some important considerations. First, the results presented here relate to the efforts made by early Jamestown settlers at establishing an industrial enterprise with a specific focus on the prospection for potentially valuable mineral resources. Gold and silver were of course the most sought after, but sources of copper, zinc and tin that could boost English metallurgical industry were highly desired too. Second, the variability in the composition and mineralogy of the slag layers is indicative of the geological complexity of the minerals subjected to crucible analysis, and it suggests that various reagents in the form of fluxes and fuel were also added. At the same time, the recurrent presence of some elements is consistent with the exploitation of the same underlying geology, namely, the ore bodies of Virginia where polymetallic sulphides are rather common.

\section{Noble metals testing}

Of the suites of elements that tend to recur in association among the samples analysed one comprises tin, copper, zinc, lead, iron, silver, sulphur and barium. Associations of this kind are also reported by Martinón-Torres and Rehren (2007, 88). In Virginia, silver could be mined from mixed sulphide lenses where minerals such as chalcopyrite, pyrrhotite, galena and sphalerite are often associated with tin-bearing minerals, and barite constitutes a common gangue component (Edmunson 1938: 9; Koschmann et al. 1942). The selection of different fractions within similar ore bodies can cause the compositional differences witnessed here between slag matrices, like the prevalence of certain elements over others. A second noticeable association of elements is that of nickel, arsenic, cobalt, antimony, lead, iron and silver as found in the metallic prills of samples JR 1339C and JR 392A. The former also shows high levels of barium oxide in the slag matrix (Table 2). Mixed cobaltnickel-arsenic minerals of this kind were well-known among silver miners of early modern central Europe and variably called cadmia or kobelt (Hoover and Hoover 1950: 111-114). These minerals can be found in Virginia in association with pyrites and pyrrhotite (Watson 1907: 578) as well as barite (see above). It would seem that rather pure pyrite was also tested by Jamestown assayers, probably in the hope of finding precious metals. Evidence for the assay of this mineral is provided by sample A-630, with its glassy iron-rich residue and metallic prills made 
Table 8 Composition of bulk areas of "other" samples. (SEM-EDS analyses, in wt\%)

\begin{tabular}{lllllllllllll}
\hline Sample & $\mathrm{Na}_{2} \mathrm{O}$ & $\mathrm{MgO}$ & $\mathrm{Al}_{2} \mathrm{O}_{3}$ & $\mathrm{SiO}_{2}$ & $\mathrm{P}_{2} \mathrm{O}_{5}$ & $\mathrm{SO}_{3}$ & $\mathrm{Cl}$ & $\mathrm{K}_{2} \mathrm{O}$ & $\mathrm{CaO}$ & $\mathrm{TiO}_{2}$ & $\mathrm{MnO}$ & $\mathrm{FeO}$ \\
\hline JR2G & 0.8 & 2.8 & 1.6 & 63.5 & 1.9 & 0.4 & bdl & 4.5 & 22.6 & 0.3 & 0.7 & 0.9 \\
JR2436B & 1.2 & 3.9 & 14.9 & 50.3 & 1.3 & bdl & bdl & 3.2 & 20.1 & 0.9 & 0.6 & 3.5 \\
JR2718M & 1.8 & 1.6 & 14.7 & 66.9 & 0.2 & 0.3 & 0.3 & 4.4 & 5.1 & 0.6 & bdl & 3.9 \\
\hline
\end{tabular}

$b d l$ below detection limit

of iron and a little copper. A similar assemblage was found in one of the crucibles analysed in 2007, although the iron minerals were richer in nickel (Martinón-Torres and Rehren 2007: 9194). Pyrites were highly regarded in early modern times. Green vitriol, an iron sulphate that forms through the weathering of pyrite, was an important ingredient in alchemical procedures such as the manufacture of medicines, and an element of philosophical theories regarding the genesis of metals (Roos 2008). Even though pyrites may contain gold as a minor element, because of their shiny appearance, they were often mistaken for much richer gold ores and for this reason known as 'fool's gold'. Loads of worthless pyrite had been shipped back home during the first colonisation of Canada by French explorers in the latter part of the 16th century (Hogarth 1999; Monette 2013: 91), and it has been suggested that the same may have happened at Jamestown too (Barbour 1969: 108).

The three samples with residual feldspar inclusions (JR 1957A, JR 1545C and JR 392A) are largely different from the rest of the assemblage both in terms of the chemical composition of their slag matrices and because they do not contain clear metallurgical residues. A number of crucibles with a very similar residue to this have been recently interpreted as evidence of glassmaking at colonial Jamestown (Owen et al. 2014). Historical documents record the existence of a "tryal of glasse" produced by German glassmakers shortly after the arrival of the first supply ships in 1608 (Smith 1907: 147; Harrington 1972). However, there are a number of observations that seem to cast serious doubts on the interpretation provided by Owen and collaborators, which are the focus of a separate paper (Rehren et al. 2019). Here, we provide a different interpretation that sees these crucibles also as metallurgy-related. Indeed, all the mineral deposits mentioned above contain feldspathic rocks as gangue components (Pegau 1937: 36), and it is possible to imagine that Jamestown's assayers found these minerals worth testing. In particular, sample JR 392A contains fragments of lead-rich feldspars and a scatter of tiny metallic prills (Fig. 5b-d). This probably represents feldspar intergrown with galena that might well have attracted the attention of metallurgists. Moreover, there is one larger lead prill trapped in the crucible fabric containing the pattern of impurities already
Fig. 6 SEM-BSE micrographs showing the microstructure of "other" samples. a Lead chloride matrix and lead sulphide prills on JR 2718W (magnification $\times 100$ ). b JR $2718 \mathrm{M}$ with remnants of feldspar inclusions (light grey) $(\times$ 200). c Glassy residue on JR 2436B showing high interaction with crucible fabric (magnification $\times 27$ ). $\mathbf{d}$ Detail of the glassy residue in the same sample showing the cell-like structure characteristic of charcoal impression (arrow), and tiny iron prills around it (magnification $\times$ 450)
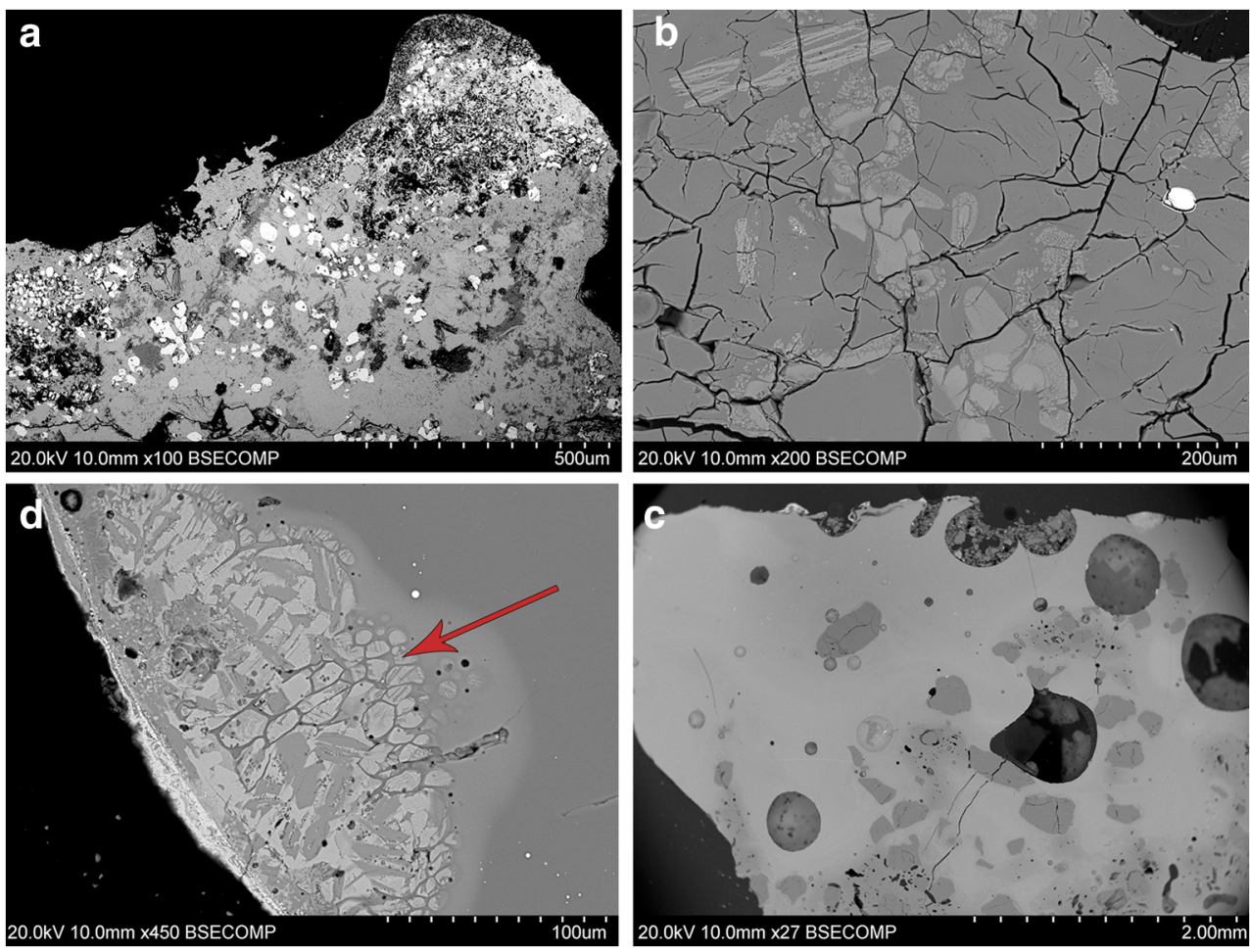
discussed above, including arsenic, nickel, antimony, sulphur and iron. Therefore, the three crucibles contain what is left of fire assay operations on feldspars associated with the ores that were being collected and tested.

\section{Zinc and tin testing}

Besides prospecting for precious metals, settlers were also interested in finding local sources of metals that could be used in the production of copper alloys. Indeed, many of the Virginia Company shareholders had ties with the English copper industry and hoped that the colonial venture would have the effect of making England less dependent on imports from Europe. For this reason, the discovery of several thousand pieces of scrap copper offcuts at Jamestown has been connected to the desire of testing local minerals for alloying purposes (Hudgins 2005; Hudgins et al. 2009). The results outlined here further point in this direction. Crucible JR 2361D can be linked to an attempt at producing brass through the cementation of copper and a local zinc mineral. The impurities detected in the metal (see "Copper metallurgy" section) and the presence of sulphur around one of the prills are strong clues in this direction and against simple melting of brass. Elements such as lead, nickel, arsenic, antimony and silver are consistent with Virginian sphalerites and the associated complex polymetallic ores already mentioned (Wright and Raman 1948; Sweet et al. 1989). There is also a piece of documentary evidence written by the Spanish ambassador in London that offers partial confirmation that the colonists had indeed found a way to make brass (Hudgins 2005: 61). Sample JR 1115B indicates that Jamestown settlers also tested the quality of tin minerals for copper alloy purposes. Active alloying of copper with a fresh source of tin is indicated by the tin levels in the metallic prills ranging from just a few percent to exceptionally high tin levels (Table 5) (Rademakers et al. 2018; Rademakers and Farci 2018; Renzi and Rovira-Llorens, 2016). It is harder to say whether the alloying process made use of tin in metallic or mineral form. Some considerations seem to make the latter option more likely. First, the clusters of tin oxide crystals visible in Fig. 4d might represent relics of cassiterite, as also indicated by the occasional presence of tantalum-rich inclusions. Second, the hypothesis of the cementation of cassiterite and English copper is consistent with the scenario reconstructed so far, of tests and experiments with local minerals. Finally, Hudgins and collaborators analysed similar masses of waste copper and came to the same interpretation (Hudgins et al. 2009: 174-175).

\section{Chemistry and experiments between Old and New World}

It is now common practice among historians of science to use the archaic term 'chymistry' to refer to the whole spectrum of laboratory operations that traditional historiography often tried too hard to artificially classify between 'alchemy' and 'chemistry' (Newman and Principe 1998; Principe and Newman 2001). This all-encompassing term avoids presentist biases and encapsulates the idea of a discipline which, through the work in the furnace and the manipulation of substances, aimed at understanding nature, creating things, bringing about transformation and making profits, often all at the same time. Such "chymists" were among the individuals sent to Virginia in 1608. Their names and professions that spanned from apothecaries to refiners and metallurgists to glassmakers were recorded by Captain John Smith in his chronicles (Smith 1907: 113-114) and their aim was to build the basis for a long-lasting industrial enterprise in the New World. Mineral resources and precious metals in particular were probably the most sought-after commodities, but Virginia seemed promising for other industries too. Glass manufacture, for instance, could benefit from exploiting the vast and untouched forests.

In the last decade, the analysis of comparable assemblages of laboratory equipment and early modern scientific contexts has grown and can complement the picture derived from written documentation. The investigation of one of the most intriguing and well-preserved of such contexts, the laboratory of Oberstockstall in Austria, revealed intricate details of a consistent assaying and cupellation procedure, as well as some experiments that deviated from the codified practice of contemporary manuals (Mongiatti et al. 2009a, b). Experimentation was also at the heart of Oxford's Old Ashmolean laboratory, home of the first chair of Chemistry in England in the 1680s (Gunther, 1923-1945; Sherwood Taylor 1949; Debus 1990; Roos 2014). The analysis of the ceramic tools recovered archaeologically revealed that a startling variety of processes were being carried out, from zinc distillation to the production of lead crystal and glass enamels (Martinón-Torres 2012; Veronesi 2019). The artisans working in Jamestown came from the same European tradition but they had to face a wholly new and unfamiliar natural environment, which is reflected in the degree of chemical variability discovered in the crucibles analysed. Assemblages of laboratory apparatus were found at other transatlantic sites, such as Quebec (Monette 2013), Latin America (Deagan and Cruxent 2002; Thibodeau et al. 2007; Martinón-Torres et al. 2018) and even at the lost colony of Roanoke (Nöel Hume 1994). The New World offered not only new opportunities but also great challenges for natural philosophy. Hence, early colonial contexts with laboratory-related remains are key sources for the history of chemistry and experimentalism. At Jamestown, the industrial venture was never able to take off the way the Virginia Company investors had hoped for, and the efforts soon ceased. This failure has been at times attributed to the laziness and incompetence of the colonists (Morgan 1975). On the contrary, the archaeological record indicates that skilled professionals were at work, employing some of the most technically 
advanced laboratory equipment available at their time. The data presented here gives a sense of how early settlers did try to understand materials through furnace tests, following an experimental attitude deeply embedded in early modern European culture of the time. They collected various ores during inland expeditions and tried them in search for precious metals, as well as zinc and tin sources useful for copper metallurgy. The geological complexity of the area, with several metals occurring in the same sulphidic lenses, must have added to the difficulty of making sense of the new environment. Moreover, in responding to accusations of idleness in the under-performing colony, Captain John Smith informed the Virginia Company in 1624 that exceptional difficulties kept the settlers from fulfilling their duties (Smith 1907: 147-150). The results presented here seem to support Smith's defence of his men and suggest that the craftsmen tried their best while pressured by historically documented famine, diseases, and clashes with the Virginia Indian population.

\section{Conclusion}

This paper has presented new data on the archaeological remains related to early chemistry and mineral prospection at colonial Jamestown, the first English settlement on the American continent. Building on previous works, the results offer new insight regarding the range of metallurgical experiments carried out and raw materials utilised, for which virtually nothing is known from documentary evidence, and which clearly spanned both noble and base metals. Our results inform about how early modern European chymists sent to the New World interacted with an unknown environment and tried to make sense of it by manipulating substances in the furnace. The paper also highlights the usefulness of approaching historical questions on early modern science and natural philosophy through the lenses of material culture and archaeometry and by integrating the information obtained from historical documents. The study of artisanal practice can inform about unwritten knowledge (Smith 2014), and when this is approached through archaeological materials it can fill gaps, clarify contradictions and address some of the biases of texts (Martinón-Torres and Rehren 2008; Andrén 1998). Increasingly, the archaeology of alchemy and early chemistry is revealed as a powerful tool for historians and archaeologists alike, and it is hoped that this emerging tradition will continue to prosper.

Funding information This study is part of U. Veronesi's $\mathrm{PhD}$ project, generously funded by the Arts and Humanities Research Council (AHRC) through the London Arts and Humanities Partnership (LAHP) scheme (Award ref. 1738300). Background research and sampling was facilitated by an AHRC Fellowship awarded to M. Martinón-Torres(ref. AH/I022228/1). We are grateful to the Jamestown Rediscovery Project for support and access to materials and we thank the two anonymous reviewer whose comments helped improve this paper. Analytical work was carried out at the Wolfson Archaeological Science Laboratories, UCL Institute of Archaeology. We are indebted to Tom Gregory and Agnese Benzonelli for the technical support and the constant help throughout the analysis.

Open Access This article is distributed under the terms of the Creative Commons Attribution 4.0 International License (http:// creativecommons.org/licenses/by/4.0/), which permits unrestricted use, distribution, and reproduction in any medium, provided you give appropriate credit to the original author(s) and the source, provide a link to the Creative Commons license, and indicate if changes were made.

\section{References}

Addyman T (2015) Materia chemica: excavation of the early chemistry stores at Old College, University of Edinburgh. In: Anderson RGW (ed) The Cradle of Chemistry: The Early Years of Chemistry at the University of Edinburgh, pp 115-130.

Andrén A (1998) Between artefacts and texts. Historical Archaeology in Global Perspective. Springer, New York

Barbour PL (ed) (1969) The Jamestown Voyages Under the First Charter, 1606-1609. Cambridge University Press, New York

Bayley J, White H (2013) Evidence for workshop practices at the Tudor mint in the Tower of London. In: Saunders D, Spring M, Meek A (eds) In the Renaissance Workshop. Archetype Publications, London, pp 138-151

Beaudoin G, Auger R (2004) Implications of the mineralogy and chemical composition of lead beads from Frobisher's assay site, Kodlunarn Island, Canada: prelude to Bre-X? Can J Earth Sci 41: 669-681

Deagan K, Cruxent JM (2002) Archaeology at La Isabela. America's first European Town. Yale University Press, New Heaven (CT)

Debus A (1990) Chemistry and the universities in the 17th century. Estud av 4(10):173-196

Debus A (1998) Chemists, physicians, and changing perspectives on the scientific revolution. Isis 89(1):66-81

Dungworth D (2000) Serendipity in the foundry? Tin oxide inclusions in copper and copper alloys as an indicator of production processes. Bull Metals Mus 32:1-5

Dungworth D (2011) The value of historic window glass. Hist Environ 2(1):21-48

Dungworth D (2012) Three and a half centuries of bottle manufacture. Ind Archaeol Rev 34(1):37-50

Dungworth D, Cromwell T, Ashurst D, Cumberpatch C, Higgins D, Willmott H (2013) Glass and pottery manufacture at Silkstone, Yorkshire. Post Medieval Archaeol 40(1):160-190

Dupré S (ed) (2014) Laboratories of art, alchemy and art technology from antiquity to the 18 th century. Springer

Edmunson RS (1938) Barite deposits of Virginia. Virginia Geological Survey Bulletin 53. Univ Virginia

Farci C, Martinón-Torres M, Álvarez DG (2017) Bronze production in the Iron Age of the Iberian peninsula: the case of El Castru, Vigaña (Asturias, NW Spain). J Archaeol Sci Rep 11:338-351

Girbal B (2011) Roman and Medieval litharge cakes. A scientific examination. English Heritage Research Department Report Series 51.

Gunther RT (1923-1945) Early Science in Oxford, vol 1 and 12. Clarendon, Oxford

Harrington JC (1972) A trial of glasse. The story of glassmaking at Jamestown. The Dietz Press Incorporated, Richmond 
Hoover HC, Hoover LH (1950) De Re Metallica, Georgius Agricola, Translated from the first Latin edition of 1556. Dover Publications Inc, New York

Hogarth DD (1999) Martin Frobisher's largest 'gold mine' in Baffin Island. Hist Metall 33(2):85-92

Hsu Y, Martinón-Torres M (2019) Fire assay and cupellation at the late Medieval Porto mint, Portugal: a technological study. J Archaeol Sci Rep 24:496-506

Hudgins CC (2005) Articles of exchange or ingredients of New World metallurgy? An examination of the industrial origins and metallurgical functions of scrap copper at early Jamestown (c. 1607-17). Early Am Stud Interdiscipl J 3(1):32-64

Hudgins CC, Martinón-Torres M, Rehren Th (2009) From the mines to the colonies: archaeological evidence for the exchange and metallurgical usage of English copper in early 17th century Ireland and Virginia. In: Horning A, Brannon N (eds) Ireland and Britain in the Atlantic World (Irish Post-Medieval Archaeology Group Proceedings 2). Wordwell, pp 157-180

Kelso W (2017) Jamestown, the Truth Revealed. The University of Virginia Press, Charlottesville

Kelso W, Straube B (2000) Jamestown Rediscovery VI. The Association for Preservation of Virginia Antiquity.

Koschmann AH, Glass JJ, Vhay JS (1942) Tin deposits of Irish Creek, Virginia. Strategic Mineral Investigation, United States Government Printing Office: 271-296.

Liu S, Rehren Th, Chen J, Xu G, Venuan P, Larreina-Garcia D, MartinónTorres M (2015) Bullion production in imperial China and its significance for sulphide ore smelting world-wide. J Archaeol Sci 55: $151-165$

Martinón-Torres M, Rehren Th (2002) Agricola and Zwickau. Theory and practice of Renaissance brass production in SE Germany. Hist Metall 36(2):95-111

Martinón-Torres M, Rehren Th (2005a) Alchemy, chemistry and metallurgy in Renaissance Europe: A wider context for fire-assay remains. Hist Metall 39(1):14-28

Martinón-Torres M, Rehren Th (2005b) Ceramic materials in fire assay practices: a case study of 16th-century laboratory equipment. In: Prudêncio MI, Dias MI, Waerenborgh JC (eds) Understanding People Through Their Pottery: Proceedings of the 7th European Meeting on Ancient Ceramics (EMAC'03). Instituto Tecnológico e Nuclear, Lisbon, pp 139-149

Martinón-Torres M, Rehren Th (2007) Trials and errors in search of mineral wealth: metallurgical experiments in early colonial Jamestown. Rittenhouse 21(66):82-97

Martinón-Torres M, Rehren Th (2008) Archaeology, History and Science. Integrating approaches to ancient materials. Left Coast Press, Walnut Creek

Martinón-Torres M, Rehren Th (2009) Post-Medieval crucible production and distribution: a study of materials and materialities. Archaeometry 51(1):49-74

Martinón-Torres M, Rehren Th, Freestone IC (2006) Mullite and the mystery of Hessian wares. Nature 444:437-438

Martinón-Torres M, Thomas N, Rehren Th, Mongiatti A (2008a) Some problems and potentials of the study of cupellation remains: the case of post-medieval Montbéliard, France. ArcheoSciences, revue d'archéométrie 32:59-70

Martinón-Torres M, Freestone IC, Hunt A, Rehren Th (2008b) Massproduced mullite crucibles in Medieval Europe: Manufacture and material properties. J Am Ceram Soc 91(6):2071-2074

Martinón-Torres M, Lobo Guerrero J, Veronesi U, White H (2018) Goldsmithing traditions and innovations in colonial Colombia: an analytical study of crucibles from Santa Cruz de Mompox. PostMedieval Archaeol 52(2):147-169

Martinón-Torres M (2012) Inside Solomon's House: an archaeological study of the Old Ashmolean Chymical Laboratory in Oxford. Ambix 59(1):22-48
Mass V, Russow E (2015) A delivery for a pharmacy? Exceptional collection of Early Modern Age finds from the sea bed of the Tallinn Bay. Archaeol Fieldw Estonia 2015:211-224

Monette Y (2013) Ore testing at the first permanent French settlement in America, 1541-1543. Searching for the origins of fire assay crucibles used at Charlesbourg-Royal (Québec, Canada). Appl Clay Sci 82:91-100

Mongiatti A, Martinón-Torres M, Rehren Th (2009a) Testing ores for gold and silver in Renaissance Austria: New techniques, new discoveries. In: Moreau JF, Auger R, Chabot J, Herzog A (eds) Proceedings of the 36 th International Symposium on Archaeometry. Universite de Laval, Quebec, pp 37-49

Mongiatti A, Rehren Th, Martinón-Torres M, Cech B (2009b) Smelting of gold and silver ores in Renaissance Austria. Archaeometallurgy in Europe: 2nd international conference, Aquileia, Italy, 17-21 June 2007, AIM: Milan, pp 60-67.

Moorhouse S, Greenaway F, Moore CC, Bellamy CV, Nicolson WE, Biek L (1972) Medieval Distilling Apparatus of Glass and Pottery. Mediev Archaeol 16(1):79-121

Morgan ES (1975) American Slavery American Freedom: The ordeal of colonial Virginia. Norton, New York

Naga SM, Awaad M, El-Mehalawy N, Antonious MS (2014) Recycling of fish bone ash in the preparation of stoneware tiles. Interceram 0102(2014): $15-18$

Newman WR (2000) Alchemy, assaying and experiment. In: Holmes FL, Levere TH (eds) Instruments and Experimentation in the History of Chemistry. The MIT Press, pp 33-54

Newman WR (2006) Atoms and Alchemy. Chymistry and the experimental origin of the scientific revolution. University of Chicago Press, Chicago

Newman WR, Principe L (1998) Alchemy vs. chemistry: the etymological origins of a historiographic mistake. Early Sci Med 3(1):32-65

Nöel Hume I (1994) The Virginia Adventure. Roanoke to Jamestown, an archaeological and historical Odyssey. Knopf, New York

Owen JV, Greenough JD, Straube B (2014) Compositional characteristics of Jamestown "tryal" glass (Virginia ca. 1608). Hist Archaeol 48(4): 76-94

Pegau AA (1937). Pegmatite deposits of Virginia. Virginia Geological Survey Bulletin 33.

Principe L, Newman WR (2001) Some problems with the historiography of alchemy. In: Newman WR, Grafton A (eds) Secrets of Nature: Astrology and Alchemy in Early Modern Europe. Mass MIT Press, Cambridge, pp 385-434

Rademakers F, Farci C (2018) Reconstructing bronze production technology from ancient crucible slag: experimental perspectives on tin oxide identification. J Archaeol Sci Rep 18:343-355

Rademakers F, Rehren Th, Pusch EB (2018) Bronze production in PiRamesse: alloying technology and materials use. In: Ben-Yosef E, Goren Y (eds) Mining for Copper: Essays in honor of Professor Beno Rothenberg. Institute of Archaeology of Tel Aviv, pp 508-531

Rehren Th (1996) Alchemy and fire assay. An analytical approach. Hist Metall 30:136-142

Rehren Th, Nixon S (2014) Refining gold with glass - an early Islamic technology at Tadmekka, Mali. J Archaeol Sci 49:33-41

Rehren Th, Veronesi U, Martinón-Torres M (2019) Glassmaking tests at early Jamestown? Some new thoughts and data. J Glass Stud 61: 265-270

Renzi M, Rovira-Llorens S (2016) Metallurgical vessels from the Phoenician site of La Fonteta (Alicante, Spain): A typological and analytical study. In: Körlin G, Prange M, Stöllner T, Yalçin Ü (eds) From Bright Ores to Shiny Metals, Bochum, pp 143-166.

Roos AM (2008) All that glitters: fool's gold in the early-modern era. Endeavour 32(4):147-151

Roos AM (2014) The chymistry of "The Learned Dr Plot" (1640-96). Osiris 29:81-95 
Sherwood Taylor F (1949) Alchemical papers of Dr. Robert Plot Ambix 4:67-76

Sisco AG, Smith CS (1949) Bergwerk- und Probierbüchlein. A Translation from the German of the Bergbüchlein, a 16th-Century Book on Mining Geology, by Anneliese Grünhaldt Sisco and Cyril Stanley Smith, and of the Probierbüchlein, a 16th-Century Work on Assaying, with Technical Annotations and Historical Notes. The American Institute of Mining and Metallurgical Engineers, New York

Sisco AG, Smith CS (1951) Lazarus Ercker's treatise on ores and assaying, Translated from the German Edition of 1580. The University of Chicago Press, Chicago

Smith J (1907) The Generall Historie of Virginia, New-England and the Summer Isles together with the true travels, adventures and observations, and a sea grammar, Volume 1. James MacLehose and Sons, Glasgow

Smith PH (1994) The business of alchemy. Science and Culture in the Holy Roman Empire. Princeton University Press, Princeton

Smith PH (2014) Making as knowing: craft as natural philosophy. In: Smith PH, Meyers ARW, Cook HJ (eds) Ways of Making and Knowing: The material culture of empirical knowledge. The University of Michigan Press, pp 17-47

Straube B (2013) Surprises from the soil: archaeological discoveries from England's first successful transatlantic colony at Jamestown. PostMedieval Archaeol 47(2):263-280

Sweet PC, Good RS, Lovett JA, Campbell EVM, Wilkes GP, Meyers LL (1989) Copper, lead and zinc resources in Virginia. Virginia
Division of Mineral Resources Publication 93, Charlottesville, Virginia.

Thibodeau AM, Killick DJ, Ruiz J, Chesley JT, Deagan K, Cruxent JM, Lyman W (2007) The strange case of the earliest silver extraction by European colonists in the New World. PNAS 104(9):3663-3666

Thomas N (2009) L'alambic dans la cuisine? In: Ravoire F, Dietrich A (eds) Colloque de Sens, Sens, France. Publications du CRAHM, pp $35-50$

Ulseth P, Lohne O, Risvaag JA, Lohne J, Ervik T (2015) Late Medieval bone-ash cupels from the archbishop's mint in Trondheim. Fornvannen 110:267-279

Veronesi U (2019) Archaeology and early modern glassmaking recipes: The case of Oxford's Old Ashmolean laboratory. Post appeared on The Recipes Project blog (last accessed March 2019).

von Osten S (1998) Das Alchemistenlaboratorium von Oberstockstall, Monographien zur Frühgeschichte und Mittelalter-archäologie vol 6., Innsbruck

Watson TL (1907) Mineral resources of Virginia. Lynchburg, VA

White H, Kearns T (2010) Legge's Mount, the Tower of London, London. Scientific analysis of the crucibles, technology report. English Heritage Research Department Report Series 76.

Wright RJ, Raman ND (1948) The Gossan lead, Carrol County, Virginia. U.S. Geological Survey

Publisher's note Springer Nature remains neutral with regard to jurisdictional claims in published maps and institutional affiliations. 